EXTENDED REPORT

\title{
Smoking and age related macular degeneration: the number of pack years of cigarette smoking is a major determinant of risk for both geographic atrophy and choroidal neovascularisation
}

\author{
J C Khan, D A Thurlby, H Shahid, D G Clayton, J R W Yates, M Bradley, A T Moore, A C Bird, for \\ the Genetic Factors in AMD Study
}

Br J Ophthalmol 2006;90:75-80. doi: 10.1136/bjo.2005.073643

\begin{abstract}
Background/aims: There is evidence that smoking is a risk factor for age related macular degeneration (AMD). However, not all studies have demonstrated this association and several key questions about the role of smoking in AMD have still to be determined. The aim of this study was to further investigate this relation for both choroidal neovascularisation (CNV) and geographic atrophy (GA).

Methods: To investigate the relation between smoking and the risk of developing age related macular degeneration (AMD) in white people, 435 cases with end stage AMD were compared with 280 controls. All subjects had graded stereoscopic colour fundus photography and AMD was defined as the presence of GA or CNV. Smoking history was assessed using multiple parameters in a detailed questionnaire.

Results: Comparison of current and former smokers with non-smokers was consistent with smoking being a risk factor for $A M D$ but did not reach statistical significance. There was a strong association between AMD and pack years of cigarette smoking $(p=0.002)$, the odds ratio increasing with the amount smoked; for subjects with more than 40 pack years of smoking the odds ratio was $2.75(95 \% \mathrm{Cl} 1.22$ to 6.20 ) compared with non-smokers. Both types of AMD showed a similar relation; smoking more than 40 pack years of cigarettes was associated with an odds ratio of $3.43(95 \% \mathrm{Cl} 1.28$ to 9.20$)$ for GA and 2.49 (95\% $\mathrm{Cl} 1.06$ to 5.82) for CNV. Stopping smoking was associated with reduced odds of AMD and the risk in those who had not smoked for over 20 years was comparable to non-smokers. The risk profile was similar for males and females. Passive smoking exposure was associated with an increased risk of AMD IOR $1.87 ; 95 \% \mathrm{Cl} 1.03$ to 3.40 ) in non-smokers.

Conclusions: The authors have demonstrated a strong association between the risk of both GA and CNV and pack years of cigarette smoking. This provides support for a causal relation between smoking and AMD. They also show an increased risk for AMD in non-smokers exposed to passive smoking. Stopping smoking appears to reduce the risk of developing AMD.
\end{abstract}

A ge related macular degeneration (AMD) is the commonest cause of severe visual impairment in the Western world and is a significant public health problem. ${ }^{1-6}$ Studies have attempted to define avoidable risk factors in a bid to reduce the incidence of this devastating condition and smoking has been found to be a risk factor in a number of studies. ${ }^{7-15}$ However, this has not been a consistent finding, with other studies showing no association. ${ }^{16-22}$ Although this is partly the result of differing definitions of $A M D$, several key questions about the role of smoking in AMD have still to be determined and, in particular, whether the association holds for both forms of end stage diseasenamely, geographic atrophy (GA) and choroidal neovascularisation (CNV). We designed a case-control study to assess the relation between a variety of smoking behaviours and end stage AMD.

\section{METHODS}

We conducted a case-control study in the UK counties of Norfolk, Suffolk, Cambridgeshire, and Buckinghamshire from 2001 to 2003, and compared cases of choroidal neovascular membrane or geographic atrophy with spouse controls. Multicentre research ethics committee and local research ethics committee approvals were obtained for the study.

\section{Case-control selection}

Patients with AMD were ascertained from hospital ophthalmic clinics, general practices, optometrists and charitable societies for people with visual impairment. Patients with a spouse willing to act as a control were prioritised for recruitment, but cases without a spouse were also accepted. It was not the aim to match cases to their own spouse. All study subjects were examined by an ophthalmologist (JCK) and completed a detailed questionnaire on smoking history. All subjects had colour, stereoscopic fundus photography of the macular region (field 2 of the modified Airlie House classification $^{23}$ ) and photographs were graded according to the International Classification of Age-related Maculopathy and Macular Degeneration. ${ }^{24}$ In this classification the term $\mathrm{AMD}$ is reserved for the late stages of the disease, CNV (which also includes pigment epithelial detachment, PED) and GA. Patients were accepted as cases if they were confirmed to have AMD in one or both eyes. Spouses with early changes of age related maculopathy were accepted as controls. Spouses found to have AMD were reclassified as

Abbreviations: $A M D$, age related macular degeneration; $\mathrm{CFH}$, complement factor $\mathrm{H}$; CNV, choroidal neovascularisation; GA, geographic atrophy; PED, pigment epithelial detachment; RPE, retinal pigment epithelium 
cases. All subjects were selected to be white, over 50 years old, and were excluded if they had more than 6 dioptres of myopic refractive error. If pseudophakic or aphakic they were only included if a preoperative refraction was available. Cases and controls were also excluded if they had evidence of other inflammatory or retinovascular disease such as retinal vessel occlusion, diabetic retinopathy, or chorioretinitis that could contribute to the development or confound the diagnosis of maculopathy. Fundus photographs were graded at the reading centre, Moorfields Eye Hospital, London, UK, and underwent both a preliminary and final grading process blinded to their provisional status as cases or controls. Discrepancies between preliminary and final grading were adjudicated by a senior ophthalmologist (ACB). Discrepancies between photographic grading and clinical examination were decided by reference to the medical case records and any previous colour photographs or fluorescein angiography.

\section{Smoking history}

Smoking data were collected and status was assessed in the same manner for both cases and controls using a questionnaire modified from that used for the European Prospective Investigation of Cancer (EPIC) study. ${ }^{25}$ Smoking status was assessed as non-smoker, former, or current smoker, with smokers defined as subjects smoking at least one cigarette per day for a year. The questionnaire included an assessment of the number of cigarettes smoked per day in each decade of life, use of other tobacco products, extent to which subjects inhaled, and exposure to passive smoking (only assessed in non-smokers and defined as having lived in the same house as a smoker for at least 5 years). To calculate pack years of smoking, the average of number of cigarettes smoked per day was divided by 20 to give packs per day and multiplied by the total number of years of smoking. ${ }^{26}$ Smoking of other tobacco products was also assessed and converted into pack years by equating $1 \mathrm{~g}$ of loose tobacco to one cigarette; cigars were taken as equivalent to $5 \mathrm{~g}$ of tobacco and cigarillos/small cigars as $2 \mathrm{~g}$.

\section{Data analysis}

Data were analysed using logistic regression models and odds ratios for categorical variables are presented in relation to a reference category. Age was fitted as a continuous variable. Comparisons with controls were made for all cases of AMD, all cases with CNV (including cases also having GA), and all cases with GA (including cases also having CNV). Data were analysed using SPSS version 11.0 software (SPSS Inc, Chicago, IL, USA).

\section{RESULTS}

The study comprised 435 cases with end stage AMD and 280 spouse controls. Summary data are presented in table 1. Two hundred and sixty one cases had CNV as the only manifestation of AMD, 106 cases had GA only, and 68 had a mixed phenotype with both CNV and GA present in the

\begin{tabular}{|c|c|c|}
\hline & $\begin{array}{l}\text { Cases }(n=435) \text { : GA only } \\
(n=106) \text {, CNV only } \\
(n=261) \text {, mixed GA/CNV } \\
(n=68)\end{array}$ & Controls $(n=280)$ \\
\hline \multicolumn{3}{|l|}{ Mean age, years (SD) } \\
\hline All subjects & $80.2(7.0)$ & $75.6(7.6)$ \\
\hline GA only & $81.2(6.9)$ & \\
\hline CNV only & $79.8(7.1)$ & \\
\hline \multicolumn{3}{|l|}{ Sex } \\
\hline Male & $200(46.0 \%)$ & $116(41.4 \%)$ \\
\hline Female & $235(54.0 \%)$ & $164(58.6 \%)$ \\
\hline \multicolumn{3}{|l|}{ Smoking status } \\
\hline Non-smoker & $159(36.6 \%)$ & $111(39.6 \%)$ \\
\hline Former & $243(55.9 \%)$ & $152(54.3 \%)$ \\
\hline Current & $33(7.6 \%)$ & $17(6.1 \%)$ \\
\hline \multicolumn{3}{|c|}{ Mean length of time of smoking (years) (SD) } \\
\hline Former & $32.5(16.1)$ & $26.9(14.4)$ \\
\hline Current & $57.9(9.8)$ & $54.8(10.3)$ \\
\hline \multicolumn{3}{|c|}{ Mean pack years of cigarefte smoking (SD) } \\
\hline Former & $23.0(18.2)$ & $16.0(12.8)$ \\
\hline Current & $37.3(14.6)$ & $36.4(16.7)$ \\
\hline \multicolumn{3}{|c|}{ Categorical pack years of cigarette smoking } \\
\hline 0 & $159(36.6 \%)$ & $111(39.6 \%)$ \\
\hline $0.1-20$ & $123(28.3 \%)$ & $106(37.9 \%)$ \\
\hline $20.1-40$ & $100(23.0 \%)$ & $49(17.5 \%)$ \\
\hline$>40$ & $53(12.2 \%)$ & $14(5.0 \%)$ \\
\hline \multicolumn{3}{|c|}{ Categorical pack years of smoking other tobacco products } \\
\hline 0 & $324(74.7 \%)$ & $220(78.9 \%)$ \\
\hline $0.1-20$ & $99(22.8 \%)$ & $51(18.3 \%)$ \\
\hline $20.1-40$ & $8(1.8 \%)$ & $4(1.4 \%)$ \\
\hline$>40$ & $3(0.7 \%)$ (1 missing data) & $4(1.4 \%)$ (1 missing data) \\
\hline \multicolumn{3}{|c|}{ Inhaled (former and current smokers) } \\
\hline Not at all & $60(21.8 \%)$ & $37(21.9 \%)$ \\
\hline A little & $134(48.7 \%)$ & $87(51.5 \%)$ \\
\hline Deeply & $81(29.5 \%)$ (1 missing data) & $45(26.6 \%)$ \\
\hline \multicolumn{3}{|c|}{ Years since quitting smoking } \\
\hline None (current smoker) & $33(7.6 \%)$ & $17(6.1 \%)$ \\
\hline Less than 20 years & $72(16.6 \%)$ & $36(12.9 \%)$ \\
\hline 20 years or more & $171(39.3 \%)$ & $116(41.4 \%)$ \\
\hline Non-smoker & $159(36.6 \%)$ & $111(39.6 \%)$ \\
\hline \multicolumn{3}{|c|}{ Passive smoking exposure (non-smokers) } \\
\hline No & $44(27.8 \%)$ & 38 (34.5\%) \\
\hline Yes & $114(72.2 \%)$ (1 missing data) & 72 (65.5\%) (1 missing data) \\
\hline
\end{tabular}


Table 2 Comparison of cases with controls for smoking status*

\begin{tabular}{|c|c|c|c|}
\hline \multirow[b]{2}{*}{ Smoking status } & \multicolumn{3}{|c|}{ Odds ratios ( $95 \%$ confidence interval) } \\
\hline & $\begin{array}{l}\text { All cases }(n=435) v \\
\text { controls }(n=280)\end{array}$ & $\begin{array}{l}\text { All cases with CNV } \\
(n=329) v \text { controls } \\
(n=280)\end{array}$ & $\begin{array}{l}\text { All cases with GA }(n=174) \\
v \text { controls }(n=280)\end{array}$ \\
\hline Non-smoker† & 1.00 & 1.00 & 1.00 \\
\hline Former smoker & $1.12(0.79$ to 1.60$)$ & $1.04(0.72$ to 1.52$)$ & $1.12(0.71$ to 1.77$)$ \\
\hline Current smoker & $1.89(0.96$ to 3.70$)$ & $1.97(0.98$ to 3.98$)$ & 2.15 (0.93 to 4.98$)$ \\
\hline $\mathrm{p}$ Value (two tailed) & 0.18 & 0.15 & 0.20 \\
\hline
\end{tabular}

same subject, either in different eyes or in the same eye. The number of females in the case and control groups was 235 $(54.0 \%)$ and $164(58.6 \%)$, respectively. The mean age of cases was 80.2 (SD 7.0) years and of controls was 75.6 (SD 7.6) years. Increasing age was associated with increasing odds of AMD, OR 1.09 for each additional year (95\% CI 1.07 to 1.12 , $\mathrm{p}<0.0001)$ so all analyses were adjusted for age. Sex was included as a parameter in all analyses and was not found to be a risk factor for AMD.

Comparison of current and former smokers with nonsmokers was consistent with smoking being a risk factor for AMD (table 2). For current smokers the data suggested an approximate doubling of risk for both CNV and GA. However, these analyses were not statistically significant.

In the logistic regression model in table 3, there was a strong association between pack years of cigarette smoking and the risk of $\mathrm{AMD}, \mathrm{GA}$, and $\mathrm{CNV}$ and the odds ratios increased with the amount smoked. For subjects who had smoked more than 40 pack years the odds ratio for AMD was 2.75 (95\% CI 1.22 to $6.20, \mathrm{p}=0.01)$, for CNV 2.49 (95\% CI 1.06 to $5.82, \mathrm{p}=0.04$ ), and for GA 3.43 (95\% CI 1.28 to 9.20 , $\mathrm{p}=0.01$ ) compared to non-smokers. There was no significant association between pack years of smoking other tobacco products and risk of AMD. Whether subjects inhaled did not affect the risk of AMD. An alternative model including duration of smoking instead of pack years was investigated but did not fit the data so well.
For non-smokers, passive smoking exposure was found to increase risk for AMD, with odds ratio of 1.87 (95\% CI 1.03 to 3.40 ), $\mathrm{p}=0.04$ (table 4 ). The odds were similar for CNV and GA subgroups but did not reach statistical significance.

Stopping smoking was associated with reduced odds of both GA and CNV (table 5). In comparison to non-smokers, the odds ratios for AMD, GA, and CNV were all highest in current smokers, somewhat lower in subjects who stopped smoking less than 20 years ago, and lower again in subjects who stopped smoking more than 20 years ago in whom the risk was not significantly different from non-smokers.

\section{DISCUSSION}

Of the many environmental factors investigated in relation to AMD, smoking is the one most consistently found to be associated with increased risk. ${ }^{9}{ }^{10} 27$ Several case-control and population based studies have reported odds ratios typically in the range 2-5. Other studies have failed to find any association and the parameter used to assess smoking exposure may be an important contributing factor. In common with our own findings, some studies have been unable to demonstrate a clear association between AMD and whether or not subjects have ever smoked. ${ }^{11} 131721$ This emphasises the importance of looking at a variety of smoking parameters. McCarty et $a l^{11}$ argued that total length of time of smoking was the most significant factor for development of AMD rather than pack years or current or former smoking

Table 3 Comparison of cases with controls by other smoking variables*

\begin{tabular}{|c|c|c|c|}
\hline & \multicolumn{3}{|c|}{ Odds ratios ( $95 \%$ confidence interval) } \\
\hline & $\begin{array}{l}\text { All cases }(n=431) \\
v \text { controls }(n=279)\end{array}$ & $\begin{array}{l}\text { All cases with CNV }(n=326) \\
v \text { controls }(n=279)\end{array}$ & $\begin{array}{l}\text { All cases with GA }(n=172) \\
v \text { controls }(n=279)\end{array}$ \\
\hline \multicolumn{4}{|c|}{ Pack years of cigarette smoking } \\
\hline $0+$ & 1.00 & 1.00 & 1.00 \\
\hline $0.1-20$ & $0.84(0.50$ to 1.42$)$ & $0.81(0.47$ to 1.40$)$ & $0.79(0.41$ to 1.54$)$ \\
\hline $20.1-40$ & $1.62(0.86$ to 3.05$)$ & $1.51(0.77$ to 2.93$)$ & $1.65(0.74$ to 3.67$)$ \\
\hline$>40$ & $2.75(1.22$ to 6.20$)$ & $2.49(1.06$ to 5.82$)$ & $3.43(1.28$ to 9.20$)$ \\
\hline $\begin{array}{l}\text { p Value (two tailed) for } \\
\text { pack years }\end{array}$ & 0.002 & 0.007 & 0.003 \\
\hline \multicolumn{4}{|c|}{ Pack years of smoking other tobacco products } \\
\hline $0+$ & 1.00 & 1.00 & 1.00 \\
\hline $0.1-20$ & $1.34(0.83$ to 2.16$)$ & (0.83 to 2.28$)$ & $1.15(0.62$ to 2.10$)$ \\
\hline $20.1-40$ & $0.82(0.22$ to 3.00$)$ & $1.05(0.28$ to 3.96$)$ & $1.21(0.27$ to 5.36$)$ \\
\hline$>40$ & $0.28(0.06$ to 1.37$)$ & $0.13(0.01$ to 1.26$)$ & $0.67(0.14$ to 3.35$)$ \\
\hline $\begin{array}{l}\mathrm{p} \text { Value (two tailed) for } \\
\text { pack years of other } \\
\text { tobacco smoked } \\
\text { Inhaled }\end{array}$ & 0.21 & 0.18 & 0.91 \\
\hline Not at all $†$ & 1.00 & 1.00 & 1.00 \\
\hline A little & 1.01 (0.59 to 1.71$)$ & $0.96(0.55$ to 1.70$)$ & 1.09 (0.55 to 2.13$)$ \\
\hline Deeply & $1.00(0.55$ to 1.82$)$ & $1.05(0.56$ to 1.98$)$ & $0.86(0.39$ to 1.88$)$ \\
\hline $\begin{array}{l}\mathrm{p} \text { Value (two tailed) for } \\
\text { inhaled }\end{array}$ & 1.00 & 0.95 & 0.76 \\
\hline \multicolumn{4}{|c|}{$\begin{array}{l}\text { *The logistic regression model included age, sex, pack years of cigarette smoking, pack years of smoking other } \\
\text { tobacco products, and inhalation status. } \\
\text { †Denotes reference category. }\end{array}$} \\
\hline
\end{tabular}




\begin{tabular}{|c|c|c|c|}
\hline \multirow[b]{2}{*}{$\begin{array}{l}\text { Passive smoking } \\
\text { exposure }\end{array}$} & \multicolumn{3}{|c|}{ Odds ratios (95\% confidence interval) } \\
\hline & $\begin{array}{l}\text { All non-smoking cases } \\
(n=158) \\
v \text { non-smoking controls } \\
(n=110)\end{array}$ & $\begin{array}{l}\text { Cases with CNV }(n=124) \\
v \text { controls }(n=110)\end{array}$ & $\begin{array}{l}\text { Cases with GA }(n=61) \\
v \text { controls }(n=110)\end{array}$ \\
\hline $\begin{array}{l}\text { Not } \\
\text { Yes } \\
\text { p Value (two tailed) }\end{array}$ & $\begin{array}{l}1.00 \\
1.87(1.03 \text { to } 3.40) \\
0.04\end{array}$ & $\begin{array}{l}1.00 \\
1.81 \text { (0.97 to } 3.39 \text { ) } \\
0.06\end{array}$ & $\begin{array}{l}1.00 \\
1.50 \text { (0.69 to } 3.27 \text { ) } \\
0.30\end{array}$ \\
\hline
\end{tabular}

status. In our statistical modelling pack years of cigarettes proved to be a better fit to the data than number of years of smoking, and was the most significant risk factor for AMD. There was a dose-response relation with the odds ratio increasing with the amount smoked and the highest risk being in those smoking more than 40 pack years. We did observe a trend, although not statistically significant, with smoking status (table 2). However, it is apparent from table 1 that there are additional differences in smoking behaviour that are not captured by smoking status alone. For former smokers the mean length of time of smoking and the total amount smoked are both higher in cases than controls. The same applies to current smokers. This is why pack years of smoking is a better measure of risk for AMD. It is clear from these data that the amount smoked is more important than whether or not someone has ever smoked. Previously, the majority of positive associations have been demonstrated for CNV, which largely reflects the limited number of studies investigating the specific effect on the two types of end stage disease. Even in the large population based studies ${ }^{28-30}$ the small numbers of cases of GA meant that in general it was not possible to show an increased risk specifically for this form of AMD. The results of this study clearly show an increased risk for GA as well as CNV.

The mean age of the control group was slightly younger than for the cases and, since age is a well established risk factor, we adjusted for this in the analyses. We found no difference in the risk profile between men and women. We found evidence that passive smoking (living with a smoker for 5 years or more) increases risk for AMD in non-smokers. Passive smoking has been suggested to increase risk for AMD in one other study, ${ }^{15}$ which gave an odds ratio of 1.42 but did not reach statistical significance. No increased risk was demonstrated for exposure to other tobacco products. There is evidence that switching to non-cigarette tobacco products such as pipes and cigars may attenuate some of the harmful effects of cigarette smoking and this was attributed to reduced total tobacco consumption. ${ }^{31}$ In the current study, since the majority (93\%) of those using other tobacco products also smoked cigarettes, it is not possible to show a differential effect of other tobacco products. Whether or not smokers inhaled did not affect the risk of AMD but since the majority $(80 \%)$ of smokers inhaled it would also be difficult to show this effect. Because of the multivariable nature of the model fitted, and the complex associations between different smoking variables, the null associations of smoking other tobacco products and inhalation with AMD cannot be reliably interpreted.

Stopping smoking was associated with reduced odds of AMD and the risk in those who had not smoked for over 20 years was comparable to non-smokers. This is another reason why smoking should be discouraged and those who do smoke should be encouraged to stop. The benefits of giving up smoking applied to both CNV and GA.

The mechanisms of smoking as a risk factor for AMD are thought to be largely related to oxidative damage. Experimental evidence suggests that smoking impairs retinal pigment epithelium (RPE) function, resulting in a build up of waste products at the RPE/retinal interface. ${ }^{32}$ This leads to the formation of drusen and consequent damage to Bruch's membrane, allowing the in-growth of new vessels. Some of the damage may also be mediated by the direct effect of nicotine, which both potentiates PDGF mediated upregulation of endothelial smooth muscle cell proliferation ${ }^{33}$ and activates pro-inflammatory mediators. ${ }^{34}$ The development of GA following such oxidative damage is, similarly, thought to be related to the formation of drusen with subsequent atrophy of the adjacent RPE and photoreceptors. Complement mediated inflammation has also been proposed as an important mechanism in AMD and exciting new research has shown that a variant in the complement factor $\mathrm{H}(\mathrm{CFH})$ gene is associated with a higher risk for AMD. ${ }^{35-39}$ Plasma levels of CFH are known to be reduced in smokers. ${ }^{40}$

The strength of this study lies in the fact that we have been careful to choose a highly select case group with only the late forms of AMD confirmed by clinical assessment and photographic grading. Controls were examined, questioned, and photographed in exactly the same manner as the cases

Table 5 Comparison of cases with controls by years since quitting smoking*

\begin{tabular}{|c|c|c|c|}
\hline \multirow[b]{2}{*}{ Years since quitting smoking } & \multicolumn{3}{|c|}{ Odds ratios ( $95 \%$ confidence interval) for AMD } \\
\hline & $\begin{array}{l}\text { All cases }(n=435) \\
v \text { controls }(n=280)\end{array}$ & $\begin{array}{l}\text { All cases with CNV }(n=329) \\
v \text { controls }(n=280)\end{array}$ & $\begin{array}{l}\text { All cases with GA }(n=174) \\
v \text { controls }(n=280)\end{array}$ \\
\hline Non-smoker† & 1.00 & 1.00 & 1.00 \\
\hline More than 20 years & 0.91 (0.62 to 1.34$)$ & $0.85(0.57$ to 1.28$)$ & $0.92(0.56$ to 1.50$)$ \\
\hline Less than 20 years & 1.74 (1.05 to 2.99$)$ & $1.70(1.00$ to 2.89$)$ & $1.83(0.97$ to 3.47$)$ \\
\hline 0 years (current smoker) & 2.13 (1.08 to 4.22$)$ & $2.00(0.99$ to 4.05$)$ & $2.14(0.92$ to 4.97$)$ \\
\hline $\begin{array}{l}\mathrm{p} \text { Value (two tailed) for years } \\
\text { since quitting smoking }\end{array}$ & 0.01 & 0.02 & 0.05 \\
\hline
\end{tabular}


and similar exclusion criteria applied. Limitations of any study of environmental risk factors include the possibility that recall bias may confound the results. Subjects were fully informed of their involvement in a study of the causes of AMD and some may have been aware of suggestions of a possible link with smoking. It is our impression, however, that participants in this study were largely unaware of smoking as a risk factor for AMD. In addition, all the questions formed part of a larger health and lifestyle questionnaire and as such it would be difficult for a subject to discern specifically which questions may be leading to a possible link with AMD. We attempted to improve the accuracy of pack year estimation by collecting data on the number of cigarettes smoked in each decade of life. ${ }^{26}$ When analysing the results it was apparent that subjects smoked only modest amounts in their teens and during the post-war years owing to cost limitations but tended to smoke much more heavily from their 30s onwards, emphasising the importance of ascertaining information about the amount smoked throughout life.

\section{CONCLUSIONS}

We have demonstrated a clear association between the risk of AMD and pack years of cigarette smoking. This provides strong support for a causal relation between smoking and AMD. We have shown that the risk applies to both CNV and GA. We also show an increased risk for AMD in non-smokers exposed to passive smoking. Absence of an association with exposure to other types of tobacco products suggests that it is cigarettes in particular that confer increased risk. Stopping smoking appears to reduce the risk of both GA and CNV; this needs to be emphasised as a public health issue.

\section{ACKNOWLEDGEMENTS}

The following investigators also contributed to this work as part of the Genetic Factors in AMD Study: SS Bhattacharya, P Bishop, P Black, Z Butt, NE Day, C Edelsten, A Fitt, DW Flanagan, A Glenn, S Harding, C Jakeman, C Jones, RJ Lamb, A Lotery, V Moffat, C Moorman, A Nicholas, RJ Pushpanathan, E Redmond, T Rimmer. With special thanks to Tunde Peto for directing the fundus photograph grading and Kay-Tee Khaw for advice on the patient questionnaire. We also appreciate the help of the clinic staff and medical photographers at the Addenbrooke's Centre for Clinical Investigation, Cambridge; Ipswich Hospital; Peterborough District Hospital; Moorfields Eye Hospital, London; Norfolk and Norwich University Hospital, Norwich; West Suffolk Hospital, Bury St Edmunds; Queen Elizabeth Hospital, King's Lynn; James Paget Hospital, Great Yarmouth; Stoke Mandeville Hospital, Aylesbury. Many thanks to all the patients and their families who participated in this study.

\section{Authors' affiliations \\ J C Khan, D A Thurlby, H Shahid, D G Clayton, J R W Yates,} Department of Medical Genetics, University of Cambridge, Cambridge, UK

M Bradley, Centre for Applied Medical Statistics, Institute of Public Health, University of Cambridge, Cambridge, UK

A T Moore, A C Bird, Institute of Ophthalmology, University College London, London, UK and Moorfields Eye Hospital, London, UK

This work was supported by a programme grant from the Medical Research Council.

The authors declare no competing interests in the preparation and submission of this manuscript.

Multicentre research ethics committee, Trent, UK and local research ethics committee approvals from each of the participating units detailed above were obtained for the study.

\section{REFERENCES}

1 Evans $\mathrm{J}$, Wormald R. Is the incidence of registrable age-related macular degeneration increasing? Br J Ophthalmol 1996;80:9-14.
2 Evans JR. Causes of blindness and partial sight in England and Wales 19901991. Studies on Medical and Population Subjects 1995;57.

3 Hawkins BS, Bird A, Klein R, et al. Epidemiology of age-related macular degeneration. Mol Vis 1999;5:26.

4 Buch H, Vinding T, Nielsen NV. Prevalence and causes of visual impairment according to World Health Organization and United States criteria in an aged, urban Scandinavian population: the Copenhagen City Eye Study. Ophthalmology 2001; 108:2347-57.

5 Klaver CC, Wolfs RC, Vingerling JR, et al. Age-specific prevalence and causes of blindness and visual impairment in an older population: the Rotterdam Study. Arch Ophthalmol 1998;116:653-8.

6 McCarty CA, Nanjan MB, Taylor HR. Vision impairment predicts 5 year mortality. Br J Ophthalmol 2001;85:322-6.

7 The Eye Disease Case-Control Study Group. Risk factors for neovascular agerelated macular degeneration. Arch Ophthalmol 1992;110:1701-8.

8 Age-Related Eye Disease Study Research Group. Risk factors associated with age-related macular degeneration. A case-control study in the age-related eye disease study: age-related eye disease study report number 3. Ophthalmology 2000; 107:2224-32.

9 Klein R, Klein BE, Linton KL, et al. The Beaver Dam Eye Study: the relation of age-related maculopathy to smoking. Am J Epidemiol 1993;137:190-200.

10 Vingerling JR, Hofman A, Grobbee DE, et al. Age-related macular degeneration and smoking. The Rotterdam Study. Arch Ophthalmol 1996;114:1193-6.

11 McCarty CA, Mukesh BN, Fu CL, et al. Risk factors for age-related maculopathy: the Visual Impairment Project. Arch Ophthalmol 2001;119:1455-62.

12 Delcourt C, Diaz JL, Ponton-Sanchez A, et al. Smoking and age-related macular degeneration. The POLA Study. Pathologies Oculaires Liees a l'Age. Arch Ophthalmol 1998;116:1031-5.

13 Christen WG, Glynn RJ, Manson JE, et al. A prospective study of cigarette smoking and risk of age-related macular degeneration in men. JAMA 1996;276:1147-51

14 Seddon JM, Willett WC, Speizer FE, et al. A prospective study of cigarette smoking and age-related macular degeneration in women. JAMA 1996;276:1141-6

15 Smith W, Mitchell P, Leeder SR. Smoking and age-related maculopathy. The Blue Mountains Eye Study. Arch Ophthalmol 1996;1 14:1518-23.

16 Hyman LG, Lilienfeld AM, Ferris FL III, et al. Senile macular degeneration: a case-control study. Am J Epidemiol 1983;118:213-27.

17 Kahn HA, Leibowitz HM, Ganley JP, ef al. The Framingham Eye Study. I. Outline and major prevalence findings. Am J Epidemiol 1977; 106:17-32.

18 Maltzman BA, Mulvihill MN, Greenbaum A. Senile macular degeneration and risk factors: a case-control study. Ann Ophthalmol 1979;1 1:1197-201.

19 Blumenkranz MS, Russell SR, Robey MG, et al. Risk factors in age-related maculopathy complicated by choroidal neovascularization. Ophthalmology 1986;93:552-8.

20 West SK, Rosenthal FS, Bressler NM, et al. Exposure to sunlight and other risk factors for age-related macular degeneration. Arch Ophthalmol 1989; 107:875-9

21 Chaine G, Hullo A, Sahel J, et al. Case-control study of the risk factors for age related macular degeneration. France-DMLA Study Group. Br J Ophthalmol 1998;82:996-1002.

22 Klein R, Klein BE, Jensen SC, et al. Age-related maculopathy in a multiracial United States population: the National Health and Nutrition Examination Survey III. Ophthalmology 1999;106:1056-65.

23 Diabetic Retinopathy Study. Report Number 6. Design, methods, and baseline results. Report Number 7. A modification of the Airlie House classification of diabetic retinopathy. Prepared by the Diabetic Retinopathy. Invest Ophthalmol Vis Sci 1981;21:1-226.

24 Bird AC, Bressler NM, Bressler SB, et al. An international classification and grading system for age-related maculopathy and age-related macular degeneration. The International ARM Epidemiological Study Group. Surv Ophthalmol 1995;39:367-74.

25 Smith MR, Kinmonth AL, Luben RN, et al. Smoking status and differential white cell count in men and women in the EPIC-Norfolk population. Atherosclerosis 2003; 169:331-7

26 Bernaards CM, Twisk JW, Snel J, et al. Is calculating pack-years retrospectively a valid method to estimate life-time tobacco smoking? A comparison between prospectively calculated pack-years and retrospectively calculated pack-years. Addiction 2001;96:1653-61.

27 Smith W, Assink J, Klein R, et al. Risk factors for age-related macular degeneration: pooled findings from three continents. Ophthalmology 2001;108:697-704.

28 Klein R, Klein BE, Linton KL. Prevalence of age-related maculopathy. The Beaver Dam Eye Study. Ophthalmology 1992;99:933-43.

29 Mitchell P, Smith W, Attebo K, et al. Prevalence of age-related maculopathy in Australia. The Blue Mountains Eye Study. Ophthalmology 1995; 102: 1450-60.

30 Vingerling JR, Dielemans I, Hofman A, et al. The prevalence of age-related maculopathy in the Rotterdam Study. Ophthalmology 1995; 102:205-10.

31 Wald NJ, Watt HC. Prospective study of effect of switching from cigarettes to pipes or cigars on mortality from three smoking related diseases. BMJ 1997;314:1860-3.

32 Bailey TA, Kanuga N, Romero IA, et al. Oxidative stress affects the junctional integrity of retinal pigment epithelial cells. Invest Ophthalmol Vis Sci 2004; 45:675-84.

33 Suner IJ, Espinosa-Heidmann DG, Marin-Castano ME, et al. Nicotine increases size and severity of experimental choroidal neovascularization. Invest Ophthalmol Vis Sci 2004;45:311-7. 
34 Sastry BV, Hemontolor ME. Influence of nicotine and cotinine on retinal phospholipase A2 and its significance to macular function. J Ocul Pharmacol Ther 1998; 14:447-58.

35 Haines JL, Hauser MA, Schmidt S, et al. Complement factor $\mathrm{H}$ variant increases the risk of age-related macular degeneration. Science 2005;308:419-21.

36 Edwards AO, Ritter R III, Abel KJ, et al. Complement factor H polymorphism and age-related macular degeneration. Science 2005;308:421-4.

37 Klein RJ, Zeiss C, Chew EY, et al. Complement factor $\mathrm{H}$ polymorphism in agerelated macular degeneration. Science 2005;308:385-9.
38 Hageman GS, Anderson DH, Johnson LV, et al. A common haplotype in the complement regulatory gene factor $\mathrm{H}$ (HF1/CFH) predisposes individuals to age-related macular degeneration. Proc Natl Acad Sci USA 2005; 102:7227-32.

39 Zareparsi S, Branham KE, Li M et al. Strong association of the $\mathrm{Y} 402 \mathrm{H}$ variant in complement factor $\mathrm{H}$ at $1 \mathrm{q} 32$ with susceptibility to age-related macular degeneration. Am J Hum Genet 2005;77:149-53.

40 Esparza-Gordillo J, Soria JM, Buil A, et al. Genetic and environmental factors influencing the human factor $\mathrm{H}$ plasma levels. Immunogenetics 2004;56:77-82.

\section{Clinical Evidence-Call for contributors}

Clinical Evidence is a regularly updated evidence-based journal available worldwide both as a paper version and on the internet. Clinical Evidence needs to recruit a number of new contributors. Contributors are healthcare professionals or epidemiologists with experience in evidence-based medicine and the ability to write in a concise and structured way.

Areas for which we are currently seeking contributors:

- Pregnancy and childbirth

- Endocrine disorders

- Palliative care

- Tropical diseases

We are also looking for contributors for existing topics. For full details on what these topics are please visit www.clinicalevidence.com/ceweb/contribute/index.jsp

However, we are always looking for others, so do not let this list discourage you.

Being a contributor involves:

- Selecting from a validated, screened search (performed by in-house Information Specialists) epidemiologically sound studies for inclusion.

- Documenting your decisions about which studies to include on an inclusion and exclusion form, which we keep on file.

- Writing the text to a highly structured template (about 1500-3000 words), using evidence from the final studies chosen, within 8-10 weeks of receiving the literature search.

- Working with Clinical Evidence editors to ensure that the final text meets epidemiological and style standards.

- Updating the text every 12 months using any new, sound evidence that becomes available. The Clinical Evidence in-house team will conduct the searches for contributors; your task is simply to filter out high quality studies and incorporate them in the existing text.

If you would like to become a contributor for Clinical Evidence or require more information about what this involves please send your contact details and a copy of your CV, clearly stating the clinical area you are interested in, to CECommissioning@bmigroup.com.

\section{Call for peer reviewers}

Clinical Evidence also needs to recruit a number of new peer reviewers specifically with an interest in the clinical areas stated above, and also others related to general practice. Peer reviewers are healthcare professionals or epidemiologists with experience in evidence-based medicine. As a peer reviewer you would be asked for your views on the clinical relevance, validity, and accessibility of specific topics within the journal, and their usefulness to the intended audience (international generalists and healthcare professionals, possibly with limited statistical knowledge). Topics are usually 1500-3000 words in length and we would ask you to review between 2-5 topics per year. The peer review process takes place throughout the year, and out turnaround time for each review is ideally 10-14 days.

If you are interested in becoming a peer reviewer for Clinical Evidence, please complete the peer review questionnaire at www. clinicalevidence.com/ceweb/contribute/peerreviewer.jsp 